\title{
Vaccination of man with attentuated live adenovirus
}

\author{
BY GRISELDA HITCHCOCK, D. A. J. TYRRELL AND M. L. BYNOE \\ Common Cold Research Unit of the Medical Research Council, Salisbury, Wilts
}

(Received 23 March 1960)

\section{INTRODUCTION}

It is known that infections with certain members of the adenovirus group, particularly serotypes 3,4 and 7 , may be important causes of acute respiratory diseases-pharyngitis or febrile catarrh-in service-men and children. These diseases may be associated with conjunctivitis or virus pneumonia. It has been shown that men can be immunized against these viruses by polyvalent-killed virus vaccines (Huebner, Bell, Rowe, Ward, Suskind \& Hartley, 1955; Bell, Ward, Huebner, Rowe, Suskind \& Paffenbarger, 1956; Hilleman, Stallones, Gauld, Warfield \& Anderson, 1956; Hilleman, Warfield, Anderson \& Werner, 1957; Hilleman, Flatley, Anderson, Luecking \& Levinson, 1958; Hilleman, Greenberg, Warfield, Anderson \& Glabere, 1958; Stallones, Hilleman, Gauld, Warfield \& Anderson, 1957; Gundelfinger, Hantover, Bell, Loosli \& Rowe, 1958; Culver, Lennette, Flintjer, Stevens \& Fox, 1959; Culver, Lennette, Fox \& Flintjer, 1959).

The vaccines were usually prepared by formalin treatment of pools of virus prepared in monkey kidney tissue cultures, and the methods employed were similar to those used in manufacturing poliomyelitis vaccine. The vaccines increased the level of circulating neutralizing antibody and reduced the attack rate of disease due to adenoviruses.

This paper reports preliminary experiments designed to determine whether living attenuated adenoviruses could be used as vaccines.

\section{MATERIALS AND METHODS}

\section{Preparation of virus pools}

It has been shown (Roden, Pereira \& Chaproniere 1956; Huebner et al. 1955) that adenoviruses passed in tissue cultures of human or monkey cells can still produce obvious illness when inoculated into man. We therefore sought strains which had been passed repeatedly in non-primate cells.

Dr F. P. Nagler kindly supplied strains of adenovirus Types 3, 4 and 7, which had been adapted to pig kidney cells (Guerin \& Guerin, 1957).

The viruses were passed by inoculating $0.2 \mathrm{ml}$. of undiluted culture fluid into pig kidney cell cultures in roller tubes as described below. A cytopathic effect, very similar to that caused by adenoviruses in HeLa cells, was seen after 7-14 days, and the cells and medium were then run for $1 \mathrm{~min}$. in a blendor and stored or passed further.

The virus pools were stored at $-20^{\circ} \mathrm{C}$. In order to check the identity of the 


\section{8}

Griselda Hitchoock, D. A. J. Tyrrell and M. L. Bynoe

modified viruses and detect possible contamination with another virus, samples of the pools were mixed with specific rabbit hyperimmune serum and the mixture was inoculated into cultures of HeLa cells and pig or monkey kidney cells. These cultures were observed for 2-3 weeks, and at each change of medium fresh specific immune serum was added. If the cytopathic effect was completely neutralized the rest of the pool was used for volunteer experiments. Pool 1 was also inoculated by intracerebral and intraperitoneal routes into 1-day-old suckling mice. No illness was observed. The following virus pools were prepared for administration to volunteers and will hereafter be referred to as modified viruses:

(1) Adenovirus Type 7. Seventeen passages in monkey kidney and seven passages in pig kidney cells. Titre $10^{5 \cdot 7} \mathrm{PKID}_{50}{ }^{*} / \mathrm{ml}$. $10^{4 \cdot 2} \mathrm{HeLa} \mathrm{ID}_{50} / \mathrm{ml}$.

(2) Adenovirus Type 7. Seventeen passages in monkey kidney and seventeen passages in pig kidney cells. Titre $10^{5 \cdot 7} \mathrm{PKID}_{50} / \mathrm{ml}$. 105.7 $\mathrm{HeLa} \mathrm{ID}_{50} / \mathrm{ml}$.

(3) Adenovirus Type 4. Seventeen passages in monkey kidney and eleven passages in pig kidney cells. Titre $10^{3 \cdot 7} \mathrm{HeLa} \mathrm{ID}_{50} / \mathrm{ml}$.

\section{Preparation of tissue cultures}

HeLa cell stocks were grown in $500 \mathrm{ml}$. centrifuge bottles in a roller drum at $37^{\circ} \mathrm{C}$. in a medium containing $10 \%$ inactivated human serum, $0.5 \%$ lactalbumin hydrolysate (LAH) and $0.1 \%$ yeast extract in Hanks' saline. Trypsinization of one stock bottle gave fifty test tubes of cells which were allowed to grow to a monolayer and thereafter maintained in $5 \%$ rabbit serum, $0 \cdot 25 \% \mathrm{LAH}$ in Hanks' saline. These cultures were always kept stationary.

Pig kidney-cell monolayers were prepared in test tubes using a trypsinization method based on that of Dulbecco \& Vogt (1954) and growth medium of $15 \%$ inactivated calf serum, $0.5 \% \mathrm{LAH}$ in Hanks' saline. Kidneys were used from piglets 1-3 months old. After the first week cultures were maintained in $5 \%$ rabbit serum, $0.5 \%$ LAH in Hanks' saline. All culture media contained penicillin, streptomycin and mycostatin.

\section{Serological Methods}

Virus titrations were done by making ten-fold dilutions and inoculating $0 \cdot 2 \mathrm{ml}$. of each dilution into each of two tissue culture tubes. Final assessment of these tissue culture tubes was made at 3 weeks after their inoculation.

Complement-fixation tests (CFT) were done by the method described in the paper by Roden et al. (1956).

Haemagglutination inhibition tests (HAI) were performed in plastic plates after the method of Rosen (1958).

Serum neutralization tests were first set up with four-fold dilutions of serum in Hanks' salt solution. About $10^{2} \mathrm{TCD}_{50}$ of virus was added to each dilution and the mixtures were held at room temperature for $2 \mathrm{hr}$. when $\mathbf{0 . 2} \mathrm{ml}$. was taken from the tubes and inoculated into each to two tissue culture tubes. Final readings of the test cultures were made when the virus control cultures showed about $50 \%$ degeneration of the cell sheet.

* $50 \%$ infectious doses for pig kidney cells. 


\section{Volunteers}

Volunteers of both sexes between the ages of 18 and 45 were isolated in groups of 2 or 3 at the Common Cold Research Unit as described by Andrewes (1948). Two of the volunteers in this study (M.B. and D.T.) were members of staff and were not isolated.

After a preliminary 2 days in isolation the volunteers were given the modified virus as $1 \mathrm{ml}$. of nasal drops in Hanks' saline. Throat swabs for virus isolation were collected 1, 3 and 5 days after inoculation, immersed in $2 \mathrm{ml}$. Hanks' saline and stored at $-20^{\circ} \mathrm{C}$ until required, when the fluid was inoculated into HeLa-cell and pig kidney-cell cultures. If no specific cytopathic effect was observed after 2 weeks' incubation, the cells were ground up and passed to more cultures for a further 2 weeks before being scored as negative. Faeces were collected 5 days after inoculation of the volunteers, shaken in Hanks' saline, centrifuged at $2000 \mathrm{~g}$ for $30 \mathrm{~min}$. and the supernatants treated in the same way as throat swab fluids.

Serum samples for antibody studies were taken from volunteers on the day of inoculation and about a fortnight later.

\section{RESULTS}

\section{Results of adenovirus Type 7 trials}

The volunteers were examined every day by a physician who was unaware of the nature of their inoculum, and at the end of the series of trials, the symptoms of volunteers receiving modified virus were compared with those of volunteers who received control materials (usually uninoculated tissue culture media) in the same trials. The adenovirus Type 7 trials were mostly carried out during the winter of 1958-59 at a time when there was an unusually high incidence of mild coryza with slight abdominal symptoms even in the control volunteers. None of the test nor control volunteers were considered to have a 'cold' as understood at this unit, but a few in both groups had slight malaise and headache. One volunteer (M.B.) who was not isolated and received a very high dose of virus was ill enough to spend one day in bed.

Results of the experiments with adenovirus Type 7 are summarized in Table 1. It will be seen that when large doses of virus were used, infection occurred although circulating antibody was present before inoculation. Doses as low as $150 \mathrm{TCD}_{50}$ caused an antibody response in those volunteers whose antibody titre was less than $1 / 16$ at the time of inoculation. The post-vaccination neutralizing antibody levels against Type 7 ranged from $1 / 96$ to $1 / 512$ and preliminary observations indicate that these levels fell by about twofold in 6 months.

Table 1 shows that there were antibody rises against Type 3 virus also. This heterologous rise only occurred in volunteers who had low antibody titres against Type 7 and were therefore susceptible to the Type 7 virus with which they were inoculated.

Haemagglutination-inhibition tests showed similar antibody rises, although the method was rather less sensitive than neutralization tests.

There were no rises in CF antibody titres. 


\section{Results of adenovirus Type 4 trials}

Five volunteers were given adenovirus Type 4 . Three of them received approximately $250 \mathrm{TCD}_{50}$; no virus was recovered from the throats and no volunteers developed homologous neutralizing antibodies. Two volunteers received approximately $2500 \mathrm{TCD}_{50}$; no virus was recovered from them but they both showed antibody rises to Type 4 virus. The first showed a rise from $1 / 4$ to $1 / 64$ and the second from $1 / 64$ to $1 / 512$. Both remained well but complained of slight sore throat for one day.

Table 1. Results of inoculation of volunteers with adenoviruses passaged in pig kidney-tissue cultures

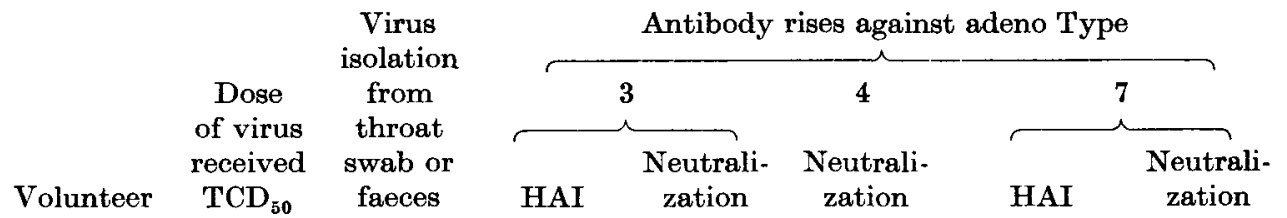

Group I. Inoculated with AD 7 passed seven times in pig kidney

$\begin{array}{lrllcccc}\text { M.B. } & 150,000 & + & <8: 24 & 4: 256 & <4: 32 & <16: 256 & 4: 512 \\ \text { D.T. } & 150,000 & + & <8: 8 & 64: 128 & 32: 32 & 64: 128 & 192: 512 \\ \text { H. } & 1,500 & + & <8: 24 & 24: 448 & <8: 8 & <16: 64 & <4: 384 \\ \text { R.M.S. } & 1,500 & 0 & <8:<8 & 8: 16 & \text { N.T.: }<8 & 48: 48 & 64: 128 \\ \text { A.S. } & 150 & + & <8: 8 & 32: 32 & \text { N.T.: }<8 & <8: 24 & <4: 96 \\ \text { M. } & 150 & 0 & <8:<8 & \text { N.T.:8 } & \text { N.T.: }<8 & 32: 32 & 16: 16 \\ \text { S.T. } & 15 & 0 & <8:<8 & <8: 16 & \text { N.T.:8 } & 12: 24 & 24: 32 \\ \text { B. } & 15 & 0 & <8:<8 & \text { N.T.:8 } & \text { N.T.:8 } & 32: 12 & 32: 8\end{array}$

Group II. Inoculated with AD 7 passed seventeen times in pig kidney

$\begin{array}{lrrlcccc}\text { W.N.R. } & 15,000 & 0 & <8:<8 & <4: 16 & \text { N.T.: }<8 & <4: 64 & 16:>256 \\ \text { P.N.M. } & 15,000 & + & <8:<8 & <4: 4 & \text { N.T.: }<8 & <4: 96 & <4: 384 \\ \text { L. } & 15,000 & + & \text { N.T. } & \text { N.T. } & \text { N.T. } & 64: \text { N.T. } & \text { N.T. } \\ \text { R.D.C. } & 150 & 0 & \text { N.T. } & 24: 64 & \text { N.T.: }: 8 & <4: 32 & <4: 128 \\ \text { R.B.C. } & 150 & 0 & \text { N.T. } & 8:<4 & 32 / 16 & 4 / 4 & 32 / 64 \\ & & & & & & & \end{array}$

Possible dangers of excreted virus

We considered the possibility that the pig kidney-modified strains might revert to virulence for man while multiplying in the volunteers and thus start an epidemic. There are three pieces of evidence which make this unlikely. (1) Virus was recovered with difficulty from volunteers and the virus in positive throat swab fluids was detected, at best, in a 1 in 10 dilution. Of the eight volunteers who showed serological evidence of infection, virus was recovered from 6 throat swabs and one faeces sample. (2) Isolation results were the same in pig kidney and HeLa-cell cultures, i.e. as judged by tissue culture studies there had been no increase in pathogenicity for the human cell at the expense of pig cell pathogenicity. (3) A second passage of the modified virus was made in human beings to see if it had regained virulence. Throat swab fluid containing virus $(a)$ from volunteers who 
had received 7 th passage virus and $(b)$ from volunteers who had received 17th passage virus was given to volunteers who had been selected for their lack of HAI antibodies to adenovirus Type 7. Of those who received material $(a)$ both showed an antibody response while none of three volunteers who received material (b) gave any antibody response. One volunteer from each group developed coryza.

The results suggest that the modified virus can be transmitted only with difficulty from man to man.

The occurrence of coryza in a volunteer of group $(b)$ who showed no serological evidence of infection throws some doubt on whether the coryza in group $(a)$ was caused by the modified virus. It is possible that both cases of coryza were caused by some cold virus which was 'picked up' after inoculation with adenovirus-a phenomenon which has previously been observed at this unit (Pereira \& Rodenpersonal communication).

\section{DISCUSSION}

We regard these experiments as an encouraging pilot study. The virus strains used produced good antibody responses when given to adults. The original culture fluids could be diluted and $1 \mathrm{ml}$. of fluid would have provided 3000 doses of $150 \mathrm{TCD}_{50}$.

It seems to us that we have now reached the stage when the matter should be investigated on larger numbers of volunteers who need not be isolated and that the procedure is likely to prove simple and economical. The vaccine will not be studied further at this unit. It remains to be seen whether it will continue to be free of troublesome side effects and will prove effective in preventing disease. Its usefulness will also, of course, depend upon how widespread and important are the adenovirus infections against which protection is desired.

\section{SUMMARY}

Eighteen volunteers were given live adenovirus attenuated by passage in pig kidney tissue culture. Thirteen were given adenovirus Type 7 and five were given adenovirus Type 4. All volunteers who were given Type 7 and who had no homologous neutralizing antibody on inoculation showed antibody rises. Except in one volunteer not in isolation no signficant symptoms were seen.

It is suggested that adenoviruses attenuated in this way might be useful for large-scale vaccination programmes.

\section{REFERENCES}

Andrewes, C. H. (1948). J. Roy. Soc. Arts, 96, 200.

Bell, J. A., Ward, T. G., Huebner, R. J., Rowe, W. P., Suskind, R. G. \& Paffenbarger, R. S., Jr. (1956). Amer. J. publ. Hlth, 46, 1130.

Culver, J. O., Lennette, E. H., Flintjer, J. D., Stevens, T. E. \& Fox, V. L. (1959) (ii). Amer. J. Hyg. 69, 112.

Culver, J. O., Lennette, E. H., Fox, V. L. \& Flintjer, J. D. (1959) (i). Amer. J. Hyg. 69, 38.

Dulbecco, R. \& Vogt, M. (1954). J. exp. Med. 99, 167.

Guerin, L. F. \& Guerin, M. M. (1957). Proc. Soc. exp. Biol., N.Y., 96, 322. 


\section{GRISELdA HITCHCOCK, D. A. J. TYRRELL AND M. L. BYNOE}

Gundelfinger, B. F., Hantover, M. J., Bell, J. A., Loosli, C. G. \& Rowe, W. P. (1958). Amer. J. Hyg. 68, 156.

Hilleman, M. R., Stallones, R. A., Gadld, R. L., Warfield, M. S. \& Anderson, S. A. (1956). Proc. Soc. exp. Biol., N.Y., 92, 377.

Hulgman, M. R., Warfield, M. S., Anderson, S. A. \& Werner, J. H. (1957) (i). J. Amer. med. Ass. 163, 4.

Himleman, M. R., Flatiey, F. J., Anderson, S. A., Luecking, M. L. \& Levinson, D. J. (1958) (ii). J. Immunol. 80, 299.

Hilleman, M. R., Greenberg, J. H., Warfield, M. S., Anderson, S. A. \& Glabere, R. R. (1958). Amer. Med. Ass. Arch. Int. Med. 102, 428.

Huebner, R. J., Bell, J. A., Rowe, W. P., Ward, T. G., Suskind, R. G. \& Hartley, J. W. (1955). J. Amer. med. Ass. 159, 986.

Roden, A. T., Pereira, H. G. \& Chaproniere, D. M. (1956). Lancet, ii, 592.

Rosen, L. (1958). Virology, 5, 574.

Stallones, R. A., Hirleman, M. R., Gauld, R. L., Warfield, M. S. \& Anderson, S. A. (1957). J. Amer. med. Ass. 163, 9. 